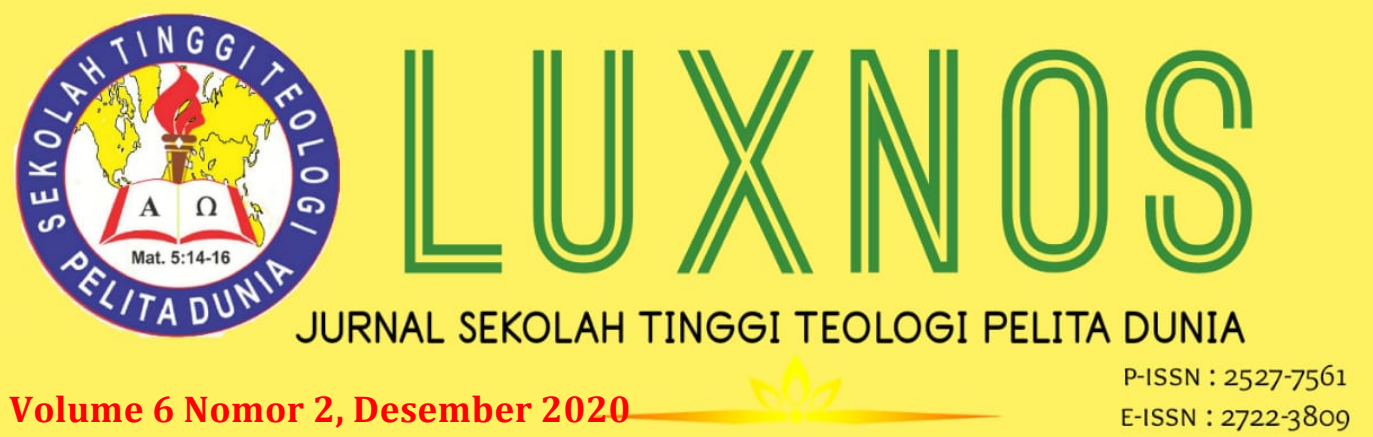

\title{
Kajian Konsep Keselamatan dalam Kitab Yunus
}

\section{Tolop Oloan Marbun}

Sekolah Tinggi Teologi Pelita Dunia

tolopmarbun@gmail.com

\begin{abstract}
This article examines about the concept of salvation based the book of Jonah. Jonah is one of the books which speaks salvation for the Gentiles. The book of Jonah will give insightful idea to answer some of the topics in salvation. The method is teological analisis. As the result salvation which is the sailaors experience are physical and spiritual salvation, Johan experienced salvation from the death and Niniwe experience complete salvation.
\end{abstract}

Keyword: Salvation, physical, spiritual

Abstrak: Artikel ini membahas tentang konsep keselamatan dalam kitab Yunus. Kitab Yunus adalah salah satu kita yang berbicara keselamatan bagi bangsa-bangsa asing. Kitab Yunus akan menjawab beberapa topik dalam keselamatan. Metode yang digunakan analisis teologis. Hasilnya adalah keselamatan yang dialami oleh para pelayar adalah keselamatan secara fisik dan spiritual, Yunus selamat dari kematian, dan orang Niniwe mengalami keselamatan yang seutuhnya.

Kata Kunci:Keselamatan, fisik, spiritual

\section{Pendahuluan}

Topik keselamatan selalu menarik perhatian para teologi sepanjang sejarah gereja karena topik keselamatan sangat vital dalam teologi Kristen. ${ }^{1}$ Dalam pembahasan topik keselamatan selalu ada perbedaan-perbedaan pemahaman. Pada zaman gereja mula-mula memahami keselamatan bisa hilang. ${ }^{2}$ Menjelang abad pertengahan, Augustinus mengembangkan teologinya perseverance of the saint ${ }^{3}$ dan

\footnotetext{
${ }^{1}$ Gregg Allison, Historical Theology: An Introduction to Christian Doctrine (Grand Rapids: Zondervan, 2011), 542-543

2 Ibid., 543-546

${ }^{3}$ Karunia yang dimiliki orang pilihan Allah untuk memastikan bahwa setiap orang percaya akan tetap setiap percaya kepada Yesus Kristus dalam segala keadaan sampai orang percaya
} 
inti pemahamannya "sekali selamat, tetap selamat" karena Allah pasti menjaga orang pilihannya. ${ }^{4}$ Pada abab pertengahan Thomas Aquinas menjadi antithesis dari pengajaran Augustinus. Menurut pemahaman Aquinas keselamatan bisa hilang karena kehendak bebas manusia yang bisa berubah-ubah. ${ }^{5}$ Perbedaan pemahaman ini masih berkesinambungan sampai saat ini.

Paul Tillich menegaskan bahwa keselamatan terjamin atau hilang tergantung bagaimana sesesorang mengartikan keselamatan. Dalam pengertian yang terbatas, orang Katolik selamat dari Purgatori dan Neraka sedangkan orang Protestan selamat dari penghukuman dosa. 6 Tillich menegaskan bahwa arti original dari "keselamatan" adalah kesembuhan. Menurut Tillich, sembuh dari estrangement. ${ }^{7}$ Kesembuhan dalam konteks ini adalah memperdamaikan kembali Allah dengan manusia, manusia dengan dunianya dan dengan diri sendiri. ${ }^{8}$

Erastus Sabdono memiliki pemikiran yang sama dengan pemikiran Tillich. Sabdono juga memulai konsep keselamatan dari pengertian keselamatan. Sabdono menyatakan bahwa terhindar dari neraka dan penghakiman yang kekal itu adalah buah keselamatan, bukan keselamatan itu sendiri. Keselamatan menurut Sabdono adalah usaha Allah untuk mengembalikan manusia kepada rancangan-Nya semula. ${ }^{9}$

Perry B. Yoder dalam bukunya Shalom: The Bible's Word for Salvation, Justice and Peace menjelaskan kata "shalom" sebagai konsep keselamatan. Yoder memahami "shalom" sebagai konsep keselamatan meliputi, keselamatan fisik (sehat, sembuh dari sakit, terhindari dari bahaya), keselamatan materi (terhindari dari kerugian, pencurian, dan perampokan), keselamatan dalam hubungan sosial (hidup rukun) dan sebagai kehendak Allah yang ultima ${ }^{10}$ yaitu manusia berdamai dengan Allah. ${ }^{11}$ Yoder menjelaskan bahwa Ierene adalah sebagai kelanjutan konsep

mengalami kematian fisik. Wayne Grudem, Systematic Theology: An Introduction to Biblical Doctrine (Grand Rapids; Zondervan, 1994),788

4Pillip Schaff, Nicene and Post Nicene Father Series 1 (Grand Rapids: Christian Classics Ethereal Library), 5:526

5 Thomas Aquinas, Summa Theologica (ErthNow, 2013), 2nd pt. of pt. 2, q.137, art.4 $165-166$.

${ }^{6}$ Paul Tillich, Systematic Theology, Vol. 2 (Chicago: The University of Chicago Press, 1962),

${ }^{7}$ Ibid., 44-47. Estrangement adalah bukan istilah Alkitab, melainkan istilah filsafat. Estrangement menjelaskan keberadaan manusia yang berdosa. Sekalipun demikian, Istilah dosa tidak bisa digantingkan dengan Estrangement. Estrangement memiliki arti, manusia tanpa iman kepada Allah dan manusia mahkluk egosentris.

8Ibid.,166-180.

9 Erastus Sabdono, Apakah Keselamatan Bisa Hilang? (Jakarata: Rehobot Literatur, 2019),1-6

${ }^{10}$ Kehendak Allah paling akhir

${ }^{11}$ Perry B. Yoder, Shalom: The Bible's Word for Salvation, Justice and Peace (Indiana: Evangel Publishing House, 1987), 11-19. 
keselamatan dari Perjanjian Lama di dalam Perjanjian Baru. Signifikansi teologis kata "Eirene" mengacu pada kematian dan kebangkitan Yesus Kristus. 12

Pemaparan di atas menunjukkan bahwa pengertian teolog tentang keselamatan sangat menentukan pengajaran teolog tersebut tentang keselamatan sekalipun memiliki sumber utama yang sama yaitu Alkitab. Oleh sebab itu perlu mengkaji Alkitab secara kitab per kitab untuk memberikan pemahaman keselamatan lebih komprehensif. Dalam Artikel ini penulis hanya mengkaji kitab Yunus.

Pada umumnya teolog mengkaji kitab Yunus dari sudut pandang kedaulatan Allah dan belaskasihan Ilahi. Dalam artikel ini, penulis mengkaji dari sudut pandang keselamatan. Dalam kitab Yunus sangat jelas digambarkan bahwa Allah berdaulat menyelamatkan bangsa asing (atau bangsa diluar bangsa Israel). Keselamatan terjadi bagi bangsa asing karena belaskasihan Ilahi, secara khusus dalam kitab Yunus adalah orang Niniwe. ${ }^{13}$

Penulis akan mengkaji keselamatan dalam kitab Yunus berdasar tahapan keselamatan. Adapun tahapan keselamatan adalah Intial salvation, Progressive Salvation, dan The Ultimate Salvation. Intial salvation adalah keselamatan yang pertama kali dialami setiap orang percaya. Progressive Salvation keselamatan yang dialami orang percaya setelah mengalami initial salvation. The Ultimate Salvatiion adalah keselamatan yang dialami oleh orang percaya setelah kematian fisik.

Kitab Yunus memiliki keunikan. Yesus menggunakan kisah Yunus sebagai tanda. Yesus berkata "Angkatan yang jahat dan tidak setia ini menuntut suatu tanda. Tetapi kepada mereka tidak akan diberikan tanda selain tanda Nabi Yunus" (Matius 12:39). Resti Arrena Pasombo menyebut kisah Yunus sebagai tipologi kematian dan kebangkitan Kristus. Penelitian yang dilakuka oleh Pasombo untuk membandingkan kisah Yunus dengan kematian dan kebangkitan Yesus Kristus. ${ }^{14}$

Gumulya Djuhato melakukan penelitian tentang Kitab Yunus. Djuharto fokus pada panggilan Yunus. Djuharto menghubungkan panggilan Yunus dan kedaulatan Allah. Hasil dari penelitiannya adalah "kedaulatan Allah yang penuh dengan anugerah dengan tujuan akhir membawa keselamatan kepada manusia yang dipilihNya. ${ }^{15}$

Paniel Mayaweng dalam penelitiannya berjudul "Utuslah Aku": Eksposisi Yunus Pasal 3-4 tentang Pengutusan Nabi Yunus Berdasarkan Persfektif Allah Menyesal"

\footnotetext{
12 Ibid., 19

${ }^{13}$ Robin Routledge, Old Testament Theology, (Illinois: IVP Academic, 2013, epub), 454

${ }^{14}$ Resti Arrena Pasombo, Kajian Biblika tentang Kisah Yunus sebagai Tipologi Kematian dan Kebangkitan Kristus (Skrp, Toraja: STAKEN, 2019), 55-58.

${ }^{15}$ Gumulya Djuharto, "ANALISA PANGGILAN YUNUS DALAM KITAB YUNUS 1:1-17", Jurnal Theologia Aletheia, Vol. 16 No. 6 (Maret 2014), 31-31
} 
menghubungkan panggilan Yunus dan kedaulatan Allah. Allah berdaulat atas kota Niniwe dan panggilan Yunus. Allah yang menyesal adalah Allah yang berdaulat dan konsisten dengan sifat-Nya pengasih, penyayang, penyabar dan berlimpahkasih setia. ${ }^{16}$

Queency Christie Wauran, dkk. membuat prosiding kitab Yunus dari sudut pandang penetapan Allah. Kesimpulannya adalah "kedaulatan Allah untuk menahbiskan atau memerintahkan atau menentukan sesuai kehendak-Nya melalui ciptaan-Nya baik manusia, binatang, tumbuhan, dan juga alam untuk tujuan-Nya sendiri."17

Dalam artikel ini fokus penulis adalah konsep keselamatan berdasarkan kitab Yunus dan kajiannya berdasarkan tahapan keselamatan. Penulis menyinggung perbedaan pemahaman konsep keselamatan sepanjang sejarah gereja untuk menunjukkan bahwa perbedaan pengajaran tentang keselamatan sangat dipengaruhi oleh pengertian keselamatan. Konsep keselamatan dalam kitab Yunus belum pernah diperdebatkan secara khusus sepanjang sejarah gereja seperti perdebatan jaminan dan kepastian keselamatan. Sekalipun demikian, penulis tetap melakukan analisis teologis untuk mengetahui lebih spesifik konsep keselamatan dalam kitab Yunus.

\section{Metode Penelitian}

Metode yang digunakan dalam penulisan ini adalah metode kualitatif dengan model analisis teologis. ${ }^{18}$ Penulis terlebih dahulu melihat kontek keselamatan dalam teks Alkitab yang akan dikaji, kemudian penulis melakukan analisis teologis.Teknik analisis datanya menggunakan analisis deskriptif. Hasil penelitian ini dituangkan dalam bentuk deskripsi.

\section{Hasil dan Pembahasan}

\section{Konsep keselamatan dalam Perjanjian Lama}

Konsep keselamatan dalam PL tidak terlepas tindakan Allah terhadap bangsa Israel, yaitu pembebasan dan pemberkatan. Pembebasan adalah tindakan Allah membebaskan bangsa Israel dari yang jahat melalui intervensi Allah sendiri.

\footnotetext{
16 Peniel Maiaweng, "UTUSLAH AKU”: EKSPOSISI YUNUS PASAL 3-4 TENTANGA PENGUTUSAN NABI YUNUS BERDASARKAN PERSFEKTIF ALLAH MENYESAL", Jurnal Jaffray, Vol. 10. No. 2 (Oktober 2012), 25-28

17 Wauran, Queency at.all., (2015). Prosiding Kitab Yunus: Pengajaran Tentang Penentuan TUHAN Dalam Kitab Yunus. 10.13140/RG.2.1.3675.7847.

18 Grant R. Osborne, The Hermeneutical Spiral: A Comprehensive Introduction to Biblical Interpretation (Illinois: InterVarsity, 1991), 171
} 
Pemberkatan adalah kelanjutan tindakan Allah untuk memelihara, memperlengkapi dan menjamin keadaan yang baik dan damai. ${ }^{19}$

Tindakan pembebasan ini mengacu pada kata "Yeshuah", "Thesuah" dan "Yesha."20 Ketiga kata ini mengambarkan Allah sebagai penyelamat. "Thesuah" memiliki arti yang sama dengan "Yeshuah" yang berarti keselamatan dan pembebasan. Kata "Thesuah" merujuk pada keselamatan atau pembebasan yang secara eksplisit dijanjikan oleh Allah. Dalam Hakim-hakim 15:1-20 menjelaskan kemenangan Simson dari bangsa Filistin. Dalam 1 Samuel 19:5, pembebasan kota oleh Allah melalui kemenangan Daud terhadap Goliat. ${ }^{21}$ Kata "Yesha" adalah sinonim dari "Yeshuah."22

Keselamatan sebagai tindakan pemberkatan bisa terlihat dari kurban-kurban persembahan. Ketika bangsa Israel berbalik kepada Tuhan dan memberikan kurbankurban sebagai bukti pertobatan bangsa Israel, maka Tuhan memberkati bangsa Israel serta memulihkan keadaan bangsa Israel. ${ }^{23}$ Keadaan yang demikian sering juga disebut sebagai shalom. Shalom memiliki arti semantik sebagi keselamatan. Shalom sebagai konsep keselamatan meliputi: keselamatan fisik, materi, sosial, dan spiritual.

Keselamatan secara materi adalah selamat dari hal-hal yang merugikan secara materi, selamat dari kerugian, selamat dari perampokan dan selamat dari hal-hal yang merugikan secara materi. Keselamatan dalam konteks sosial adalah ketika tercipta hubungan yang damai, rukun dan harmonis dengan sesama manusia dalam bermasyaratkat dan bernegara. Keselamatan dalam konteks moral adalah selamat dari akibat dari moral yang bercela dan bercacat baik dari masyarakat dan dari Allah. Keselamatan dalam kontenks kehendak Allah yang paling akhir adalah ketika Allah berdamai dengan manusia. ${ }^{24}$

Dari pemaparan di atas, penulis menyimpulkan bahwa keselamatan dalam PL selalu berkaitan dengan tindakan Allah yang membebaskan dan memberkati. Tindakan pembebasan menunjukkan bahwa Allah sendiri yang membebaskan bangsa

${ }^{19}$ Elmers A. Martens, God's Design: A focus On Old Testament Theology (Bakers Books, Grand Rapids, 1994), 45-70.

${ }^{20}$ Stephen D. Renn ed., Expository Dictionary of the Bible Word: Word Studies for key English Bible Words based on The Hebrew and Greek Texts (Massachusetts: Hendrickson Publisher,2005), 849. Bruce Demarest juga menjelaskan keselamatan dalam PL berdasarkan ketiga kata tersebut. Bruce Demarest, The Cross and Salvation: The doctrine of God (Weaton. Illinois, Crossway Books, 1997), 2526.

${ }^{21}$ Renn,Expository Dictionary, 849.

22Ibid.

${ }^{23}$ Martens, God's Desing, 53-60.

${ }^{24}$ Tolop Oloan Marbun, SHALOM SEBAGAI KONSEP KESELAMATAN YANG HOLISTIK DALAM

PERJANIIAN LAMA," JURNAL LUXNOS, 5 (2) (2019), 147-157. Retrieved from

http://luxnos.sttpd.ac.id/index.php/20_luxnos_20/article/view/23 
Israel. Tindakan pemberkatan menunjukkan tindakan Allah memelihara bangsa Israel dalam kondisi yang shalom. Dengan kata lain, baik tindakan pembebasan dan tindakan pemberkatan akan menghasilkan shalom bagi bangsa Israel.

\section{Konsep keselamatan dalam kitab Para Nabi}

Keselamatan dalam kitab para nabi selalu terkait dengan penghakiman. Penghakiman terhadap bangsa Israel dan bangsa-bangsa asing. Penghakiman terhadap bangsa Israel sebagai ganjaran yang diberikan oleh Allah kepada bangsa Israel ketika bangsa Israel berbuat jahat di mata Allah. Allah membuang bangsa Israel, dalam konteks ini, Allah membuang bangsa Israel ke kerajaan Babel. Sekalipun demikian, Allah tetap berjanji bahwa Allah akan membebaskan dan memulihkan bangsa Israel ketika bangsa Israel bertobat dan berbalik kepada Allah. 25 Pertobatan ini akan mendatangkan keselamatan bangsa Israel. Pada saat yang sama, penghakiman terjadi bagi bangsa yang menjajah bangsa Israel. Bangsa Israel akan hidup dalam kedaan yang shalom.

\section{Tahapan Keselamatan}

Initial salvation adalah tahapan pertama dalam keselamatan, ketika seseorang mengalami lahir baru. Pada saat yang bersamaan mereka juga mengalami pembenaran. Dalam tahapan keselamatan ini orang percaya dimerdekakan dari ikatan dosa, perbudakan dosa, dalam hukuman dosa. Hasilnya adalah orang percaya diadopsi dan dimasukkan ke dalam keluarga Allah. ${ }^{26}$

Progressive salvation adalah keselamatan yang dialami orang percaya setelah lahir baru, mereka dimasukkan dalam persekutuan orang kudus. Mereka harus menampilkan atau mengekspresikan keselamatan setiap hari dengan pertolongan Roh Kudus. Orang percaya juga mengalami transformasi setiap hari hingga menjadi serupa dan segambar dengan Kristus. ${ }^{27}$

The ultimate salvation adalah keselamatan yang dialami orang percaya setelah kematian fisik. Pada tahapan ini orang percaya akan diubahkan sempurna seperti

${ }^{25}$ Horst Diestrich Preuss, Old Testamen Theology Vol.2, (Kentucky: Westminster John Knock Press, 1992), 81-82.

${ }^{26}$ Tolop OIoan Marbun, Progressive Salvation: Studi Pustaka Progressive Salvation dari Sudut Pandang Moderate Calvinist berdasarkan pemikiran Norman Geisler (Dr. Diss., STT Cipanas, Cipanas, 2020), 78.

27 Ibid. 
Kristus dan masuk dalam pemuliaan. Orang percaya sudah bebas dari dosa. Orang percaya akan hidup selama-lamanya dalam kekekalan. ${ }^{28}$

\section{Keselamatan dalam Kitab Yunus}

\section{Keselamatan yang dialami oleh awak kapal dan para penumpang}

Neniwe adalah satu satu kota yang terkenal di kekaisaran Asiria. Niniwe terletak di bagian timur sungai Tigris dan timur laut Mediterania. ${ }^{29}$ Niniwe menjadi satu kota yang sangat penting pada saat kejayaan kekaisaran Asiria. Kejayaan ini dimulai dari Tiglat Pileser III (745-727 SM), kemudian dilanjutkan oleh Senekerip. Senekerip pernah membuat kota ini menjadi ibu kota kekaisaran Asiria (704-681 SM). Pada masa Esar-Haddon (680-669 SM) dan Assurbanipal (668-627SM) kekasiaran Asiria adalah kekairan paling berkuasa yang dicatat dalam Alkitab.

Kekaisaran Assiria jatuh dan hancur pada tahun 612 SM oleh Medes dan Babilonia. Niniwe juga hacur dan tinggal puing-puing saja, dan tidak pernah dibangun kembali. Xenophon menggambarkan Niniwe kota yang besar kini tinggal padang kehancuran. ${ }^{30}$ Kehancuran ini tidak terlepas dari kejahatan kekaisaran Asiria yang sangat besar. Nabi Zefanya (2:13-15) dan Nabi Nahum (3:1-7) pernah menubuatkan penghakiman atas kota ini karena kejahatannya sungguh besar. Dosa penduduk Niniwe seperti dosa Sodom dan Gumora. ${ }^{31}$

Asiria menjajah bangsa Israel beberapa dekade. Penjajahan Asiria sangat kejam dan meninggalkan kepahitan di hati orang Israel. Bangsa Asiria sering melecehkan bangsa Israel, berlaku tidak adil dan semena-mena. ${ }^{32}$ Asiria juga berniat menghancurkan kerajaan Israel dan berniat membuat kerajaan Israel hanya sejarah saja. ${ }^{33}$ Kejahatan Niniwe sangat besar dan sudah menjadi perhatian TUHAN. Kota ini penuh dengan kebohongan, pertumpahan darah, bangsa yang tidak setia dan berbuat segala jenis kejahatan. ${ }^{34}$

TUHAN berfirman kepada Yunus untuk pergi ke Niniwe dan berseru kepada penduduk Niniwe karena kejahatan penduduk kota Niniwe sudah sampai kepada TUHAN. Yunus menolak pergi ke Niniwe. Yunus memilih pergi ke Tarsis karena

28 Ibid., 82

${ }^{29}$ James Limburg, Jonah: A Commentary (Kentucky: John Knox Press, 1993), 40.

30 Ibid.

31 Philip Peter Jenson, Obadiah, Johan, Micah: A Theological Commentary (New York: T\&T Carlk, 2008),43

32 Ibid

33 Ibid, 29

34 Limburg, Jonah, 41-42. 
menurut Yunus, TUHAN meminta sesuatu yang kehilahatannya mustahil. ${ }^{35}$ Yunus merasa mustahil karena dalam konsep nabi Yunus bahwa TUHAN hanya menghasihi bangsa Israel dan menolak bangsa-bangsa.

Yunus sulit menerima kenyataan bahwa TUHAN meminta nabi dari Israel pergi ke Niniwe dan menyerukan pertobatan. Dalam logika nabi Yunus, ia lebih setuju pergi ke Niniwe hanya untuk menyerukan kehancuran Niniwe tanpa ada kesempatan untuk bertobat. Yunus lebih memilih kota Niniwe dihancurkan karena kejahatan penduduk kota tersebut. ${ }^{36}$ Yunus lebih puas jika Niniwe dihancurkan oleh TUHAN karena kejahatan Niniwe beberapa dekade yang berbekas dalam hati Yunus.

Yunus memilih lari dari panggilan TUHAN. Harapan Yunus bahwa Niniwe dihancurkan oleh TUHAN karena tidak ada seruan pertobatan. Jika orang Niniwe tidak bertobat, maka murka TUHAN akan ditimpakan dan dicurahkan ke Niniwe seperti pada saat Sodom dan Gumora. Kesukaan Yunus adalah kehancuran dan kebinasaan orang Niniwe.

Yunus sengaja tidak taat kepada TUHAN. Yunus berusaha berlari dan menjauh dari hadirat TUHAN. Phillip Peter Jenson menggambar usaha Yunus dalam ayat yang ketiga sebagai berikut,

A But Jonah arose to flee to Tarshish from the Presence of YHWH

$\mathrm{B}$ and he went down to Joppa

$\mathrm{C}$ and he found a ship

D go to Tarshish

C' and he paid his fare

B' and he went down into it

$A^{\prime} \quad$ to go with them to Tarshish from the presence of Yhwh.

Jenson menegaskan kata kunci "arose (=bangkit), went down (=turun), found (=menemukan), paid (=membayar), went down" adalah sebagai usaha Yunus yang sungguh-sunguh menjauh dari hadirat Tuhan sejauh mungkin. ${ }^{37}$

35Waren W. Wiersbe, The Wiersbe Bible Commentary (Colorado Springs: David C Cook, 2007),

${ }^{36}$ Waren W. Wiersbe, The Wiersbe Bible Commentary (Colorado Springs: David C Cook, 2007), 1442

${ }^{37}$ Jenson, Obadiah, Johan, 44-45. 
Pelarian Yunus ke Tarsis untuk menghabiskan waktu yang telah ditentukan oleh TUHAN sehingga orang Niniwe tidak pernah mendengar seruan pertobatan. Yunus ingin menghilangkan kesempatan orang Niniwe untuk bertobat sehingga Niniwe hancur total dan tinggal puing-puing pada zamannya nabi Yunus. ${ }^{38}$

TUHAN tidak tinggal diam. TUHAN tidak berbicara lewat kata-kata, tetapi TUHAN berbicara lewat ciptaannya, yaitu angin rebut dan badai besar yang bisa menghancurkan kapal yang ditumpangi oleh Yunus. Awak kapal berusaha menyelamatkan diri, bahkan sampai membuang barang-barang yang dibawah untuk meringankan kapal tersebut. Awak kapal mulai berdoa menurut agama dan kepercayaan masing-masing, tetapi Yunus memilih turun ke bagian kapal paling bawah dan tidur nyenyak sampai akhirnya dibangunkan oleh kapten untuk berdoa. ${ }^{39}$

Awak kapal dan Yunus membuat undian untuk mengetahui siapa yang bersalah dan undian kena kepada Yunus. Awak kapal meminta penjelasan dari Yunus tentang alasan mengapa awak kapal mengalami malapetaka. Yunus menjawab "Aku seorang Ibrani; aku takut akan TUHAN, Allah yang mempunyai langit, yang telah menjadikan lautan dan darat (ayat 9). Orang-orang yang ada di situ menjadi takut karena orang-orang tersebut menyadari bahwa TUHAN yang menciptakan laut sedang menghukum hamba-Nya, oleh sebab itu seluruh awak kapal menyadari bahwa mereka dalam bahaya. ${ }^{40}$

Orang-orang yang ada pada saat itu bertanya kepada Yunus tetang apa yang harus diperbuat terhadap Yunus supaya laut menjadi tenang. Yunus meminta supaya orang-orang tersebut membuangnya ke laut. Namun, awalnya awak kapal tersebut enggan. Awak kapal masih berusaha sekuat tenaga menyelamatkan kapal terebut, namun situasinya semakin memburuk dan mengancam keselamatan seluruh awak kapal.

Para awak kapal berusaha mempertaruhkan nyawa mereka untuk menyelamatan semua orang yang ada dalam kapal tersebut. Awak kapal tidak setuju jika harus mengorbankan penumpang demi keselamatan perahu dan penumpang. Namun kondisi cuaca saat itu semakin mencekam. Laut semakin bergelora, jika mereka bertahanan maka awak dan penumpang tersebut akan binasa. Pada akhirnya para awak kapal tidak ada pilihan, mereka harus mengikuti instruksi dari Yunus.

${ }^{38}$ Ibid., 40. Walalupun pada akhirnya, Niniwe tetap hancur menjadi puing-puing dan tidak pernah dibagun kembali setelah beberapa dekade kemudian.

39 Wiersbe, The Wiersbe Bible, 1442

40 Ibid. 
Yunus sebelumnya sudah memperkenalkan YHWH kepada awak kapal dan penumpang pada saat itu. Awak kapal dan penumpang sudah memiliki pengetahuan tentang YHWH dan sudah memiliki rasa takut akan TUHAN. Sebelum orang-orang di kapal tersebut membuang Yunus, orang-orang tersebut berdoa dan berseru kepada TUHAN. Pada momen ini para awak kapal dan penumpang, tidak lagi hanya pada level mengetahui YHWH, tetapi mereka sudah mulai percaya. Kepercayaan mereka diekspresikan lewat doanya (ayat 14).

Setelah orang-orang tersebut berdoa, mereka membuang Yunus ke laut, laut berhenti mengamuk. ${ }^{41}$ Hasilnya adalah "orang-orang itu menjadi sangat takut kepada TUHAN, lalu mempersembahkan korban sembelihan bagi TUHAN serta mengikrarkan nazar." (ayat 16).

Waren W. Wiersbe menegaskan bahwa para pelayar penyembah berhala tersebut mengetahui dasar teologi, keberadaan TUHANnya Yunus, penghakiman-Nya terhadap dosa, dosa para pelayar di hadapan TUHAN dan kedaulatan-Nya atas ciptaan-Nya. Tidak ada bukti bahwa para pelayar membuang "dewa atau allahnya", para pelayar menambahkan TUHAN dalam daftar dewa atau allahnya, dan melibatkan diri para pelayar dalam belas kasihan Allah. ${ }^{42}$

Rasa takut para pelayar kepada TUHAN ini adalah sebagai respons kekaguman kepada TUHAN yang diperkenalkan oleh Yunus. TUHAN melakukan persis seperti yang dikatakan oleh Yunus. ${ }^{43}$ Jenson menegaskan bahwa pengakuan nama YHWH dalam bibir para pelayar ini menunjukkan ada pertobatan yang sungguh-sungguh di antara pelayar tersebut. ${ }^{44}$

Keselamatan yang pertama dialami oleh awak kapal dan orang-orang yang ada pada saat itu selamat dari angin badai dan ombak besar. Keselamatan ini mengacu kepada keselamatan yang bersifat fisik. ${ }^{45}$ Keselamatan yang bersifat fisik maksudnya para awak kapal dan penumpang tidak mati secara fisik karena gelora laut yang mengamuk pada saat itu.

Keselamatan yang dialami oleh para awak kapal dan penumpang saat itu keselamatan secara materi. Sekalipun sudah ada beberapa barang yang sudah dibuang ke laut, setidaknya kapal tersebut dan beberapa materi lainnya masih

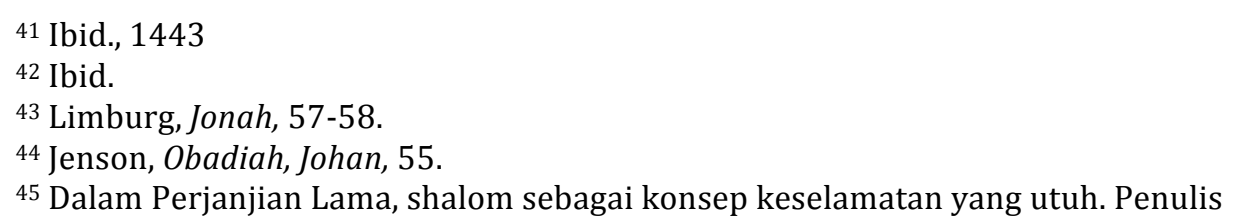
memisahkan konsep keselamatan sebagai kerangka berpikir untuk melihat penekanan keselamatan berdasarkan konteksnya. 
terselamatkan. Kerugian para awak kapal dan penumpang sebelum mereka berseru kepada TUHAN. Setelah para awak kapal dan penumpang berseru kepada TUHAN, TUHAN menyelamatkan mereka dari kerugian berikutnya.

Keselamatan secara fisik dan materi ini ini memimpin kepada shalom sebagai kehendak Allah yang ultima, ${ }^{46}$ yaitu awak kapal dan orang-orang yang ada pada saat itu berdamai dengan TUHAN. Hal ini ditunjukkan dengan persembahan sembelihan dan nazar kepada Allah yang dilakukan oleh para awak kapal dan penumpang.

Dalam pelarian Yunus jelas digambarkan usaha para awak kapal untuk menyelamatkan kapal dan para awak tidak berhasil dan tidak bisa menyelamatkan. Keselamatan para awak secara fisik terjadi ketika mereka mengikuti instruksi Yunus, sedangkan keselamatan spiritual terjadi karena respon mereka terhadap perbuatan TUHAN. Maka secara teologis, pengalama keselamatan secara fisik dan materi yang dialami seseorang bisa memimpin orang tersebut kepada pertobatan dan kehendak Allah yang ultima. Selanjutnya, usaha manusia tidak bisa menghasilakan keselamatan secara khusus keselamatan yang ultima. Keselamatan terjadi ketika manusia meresponi kedaulatan TUHAN yang diekspresikan lewat pertobatan.

Dalam konteks ini ketidaktaatan Yunus justru mendatangkan keselamatan kepada para awak kapal. TUHAN izinkan Yunus melarikan diri untuk keselamatan para awak kapal dan penumpang. Dalam hal ini kedaulatan TUHAN sungguh nyata dalam keselamatan. TUHAN berdaulat memakai ketidaktaatan Yunus untuk mendatangkan keselamatan bagi para awak kapal dan penumpang. Awak kapal dan penumpang tersebut tidak pernah memikirkan keselamatannya yang datang dari TUHAN, tetapi justru TUHANlah yang memikirkan keselamatan mereka.

Dalam tahapan keselamatan yang dialami oleh para awak kapal ini adalah Initial salvation. Para awak kapal sudah menunjukkan sikap hatinya yang mau bertobat dan memasukkan nama TUHAN menjadi salah satu dewa atau Allah mereka.

Kitab Yunus tidak menggambarkan bagaimana para awak kapal masuk dalam Progressive Salvations.

\section{Keselamatan yang dialami oleh Yunus}

Ada dua kemungkinan keselamatan yang dialami oleh Yunus. Kemungkinan ini tergantung penafsiran apakah Yunus mati atau hidup dalam perut ikan.

\section{Yunus mati dalam perut ikan}

${ }^{46}$ Ultima artinya paling akhir. 
Pendekatan ini menggunakan pendekatan leksikal. Kata "sheol" sering diterjemahkan sebagai "kuburan", "neraka" dan "lubang." Kata "sheol" sering diartikan "mengalami kematian." 47 Robert M. Solomo menegaskan bahwa "sheol" adalah dunia orang yang telah mati. ${ }^{48}$ Dalam tradisi orang Yahudi saat ini, "sheol" adalah tempat hukuman spiritual atau penyucian selama 12 bulan setelah kematian. ${ }^{49}$ Jadi "sheol" adalah tempat dunia orang mati.

Kata yang kedua "shahat" yang artinya "liang." Kata "shahat" memiliki metafora "jembakan" atau "kuburan". Kata "shahat" diterjemahkan 13 kali dengan kata "kuburan". 50 Oleh sebab itu frasa "liang kubur" adalah terjemahan yang tepat dalam pasal 2:4. Jadi berdasarkan kata "sheol" dan "shahat" Yunus mengalami kematian secara fisik dalam perut ikan.

Pengakuan Yunus "dari tengah-tengah dunia orang mati aku berteriak" menunjukkan bahwa Yunus sudah mengalami kematian fisik. Alasan berikutnya Yunus mengalami kematian karena Yesus menggunakan kisah Yunus sebagai tipologi kematian dan kebangkitan-Nya. Dalam tipologi pendekatan "language equivalent"51 (atau persamaan bahasa atau paralel) perlu diterapkankan sepenuhnya. Biasanya 3 hari yang dibuat menjadi paralel dalam tipologi. Sama seperti Yunus tiga hari dalam perut ikan, demikian juga Yesus tiga hari dalam perut bumi. ${ }^{52}$ Berdasarkan "language equivalent" Yunus juga mengalami kematian dan kebangkitan. ${ }^{53}$ Yesus menegaskan bahwa tanda yang diberikan kepada orang-orang pada zaman itu adalah tanda nabi Yunus.

Pendapat ini belum banyak dukungan dari para teolog dan ahli Biblika karena pada umum sepakat bahwa Yunus tetap hidup. Yunus menggunakan kata shakat sebagai bahasa metofora ${ }^{54}$ untuk menggambarkan posisinya dalam perut ikan yang pasti menuju kematian. Yunus menyadari tidak ada harapan baginya untuk hidup dan selamat dari perut ikan. Yunus merasakan intimidasi kematian lebih kuat dibanding peluang hidup. ${ }^{55}$ Jadi bahasa yang diucapkan Yunus dalam doanya merupakan bahasa metafora yang terintimidasi oleh bayang-bayang kematian.

${ }^{47}$ Renn, Expository Dictionary, 450.

${ }^{48}$ Robert M. Solomom, Allah sang pemburu: Pelajaran-pelajaran dari kitab Yunus, terj. Arvin Saputera (TK.: PT Duta Harpan Dunia, 2017), 79-80.

49 Www.jewfaq.com/m/search.shtml?Keyowords=sheol (diakses 22 Maret 2020).

50 Renn, Expository Dictionary, 732.

51 Osborne, The Hermeneutical Spiral, 218.

52 Beale dan Carson, Commentary on the New testament, 237.

53 Ibid., 239.

54 Renn, Expository Dictionary,732

55Walton, The IVP Bible, 779 
Langguage equivalent belum cukup membuktikan bahwa Yunus mengalami kematian dan kebangkitan karena tidak ada refrensi-refrensi pendukung yang membuktikan kematian dan kebangkitan Yunus dalam perut ikan. Langguage equivalent yang paling bisa diterima durasi waktu selama tiga hari. ${ }^{56}$

\section{Yunus hidup dalam perut ikan}

Ungkapan "dunia orang mati" (2:2) adalah sebagai ungkapan bahwa Yunus sudah kehilangan pengharapan. Yunus sulit berpikir bahwa Yunus masih memiliki kesempatan untuk hidup. Intimidasi kematian sudah merasuk jiwa Yunus. Yunus hanya menanti-nanti kematiannya dalam perut ikan. ${ }^{57}$ Kalimat "Engkau naikkan nyawaku dari dalam liang kubur" (2:6) adalah ungkapan bahwa Yunus pada saat itu menganggap perut ikan tersebut sebagai kuburan baginya. Jadi doa Yunus ini ketika Yunus memasuki detik-detik kematiannya kemudian Yunus berseru.

Doa Yunus ini tidak hanya sebagai doa orang yang ketekutan mengalami detikdetik kematian fisik. Ketakutan Yunus yang paling mengerikan adalah pada saat itu Yunus merasa terpisah dari Allah. Yunus berkata "telah terusir aku dari hadapan-Mu, mungkinkah aku memandang lagi bait-Mu yang kudus?” (2:4). Mathew Henry menegaskan bahwa doa Yunus ini menggambarkan bahwa Yunus terbuang dari hadirat Allah dan tidak terlihat lagi.58 Raja Daud pernah mengungkapkan keterpisahnnya dari Allah dengan kalimat "Allahku, Allahku mengapa engkau meninggalkan aku?" (Maz. 22:2). Yesus juga mengutip perkataan raja Daud ini untuk menggambarkan bawa Yesus terpisah dari Allah Bapa (Mark. 15:34). ${ }^{59}$

Berdasarkan pemaparan di atas keselamatan yang dialami oleh Yunus berdasarkan sudut pandang ini, Yunus selamat dari detik-detik kematian. Ada pun frasa "dunia orang mati" dan "liang kubur" adalah ungkapan Yunus yang sudah kehilangan pengharapan hidup. Yunus melihat peluang kematian sudah lebih besar dari pada peluang hidup pada saat itu. Dalam hal ini keselamatan yang dialami oleh Yunus adalah keselamatan secara fisik, yaitu Yunus terhindar dari kematian fisik.

Ketakutan Yunus bukan hanya mengalami kematian fisik tetapi terbuang dari hadirat Allah. Yunus takut terpisah dengan TUHAN selama-lamanya. Ketakutan inilah yang memotivasi Yunus berseru kepada TUHAN. Dalam doanya Yunus menunjukkan bahwa Yunus akan bertobat dan membayar nazarnya. Keselamatan ini juga mengacu

56 Robert N. Wilkin Ed. The Grace New Testatament Commentary (Denton: Grace Evangelical Sociey), 168, epub.

${ }^{57}$ Ibid. 782-783.

58 Matthew Henry, Matthew Hendry's Commentary in one Volume (Grand Rapids: Zondervan, 1961),1144.

${ }^{59}$ Beale dan Carson, Commentary on the New Testament, 1004 
kepada shalom sebagai kehendak Allah yang ultima. Kehendak Allah yang ultima dalam konteks ini, hubungan Yunus dengan TUHAN dipulihkan kembali. Walaupun setelah keluar dari perut ikan, Yunus belum menunjukkan pertobatannya, bahkan sampai kota Niniwe bertobat, Yunus belum menunjukkan pertobatannya.

TUHAN berdaulat atas segala ciptaan-NYA. TUHAN berkuasa untuk mengendalikan setiap ciptaan-NYA. Tidak ada satupun yang terjadi di luar kendali dari TUHAN. TUHAN sanggup mengendalikan ikan besar tersebut sehingga tidak melukai Yunus atau bahkan mematikan Yunus. TUHAN berkuasa memelihara Yunus dalam perut ikan selama 3 hari sehingga Yunus tidak mengalami kematian fisik.

TUHAN berdaulat atas panggilannya terhadap Yunus. Sekalipun Yunus berusaha lari dari hadapan TUHAN, TUHAN tetap mengendalikan hidup Yunus sehingga Yunus memilih untuk mentaati perintah TUHAN. Kedaulatan TUHAN ini tidak hanya mendatangkan keselamatan secara fisik bagi YUNUS tetepi juga keselamatan secara holistik bagi orang Niniwe.

Dalam kitab Yunus, nabi Yunus tidak menceritakan bagaimana pertobatan awalnya, sekalipun demikian, Yunus sebagai seorang nabi pasti sudah mengalami Initial salvation. Pergumulan Yunus tentang panggilannya ke Niniwe dan ketakutannya terpisah dari TUHAN menggambarkan pengalaman progressive salvation. Sekalipun di akhir dari kitab Yunus tidak ada tertulis kelanjutan pertobatan nabi Yunus dan tidak tertulis juga bahwa nabi Yunus kembali kepada berhala, ${ }^{60}$ nabi Yunus tetap sampai pada the ultimate salvation.

\section{Keselamatan yang dialami oleh orang Niniwe}

Tuhan berfirman yang kedua kalinya kepada Yunus untuk pergi ke Niniwe. Kali ini Yunus pergi ke Niniwe. Niniwe kota yang sangat luas, luasnya tiga hari perjalanan. Mulailah Yunus memasuki kota tersebut sehari perjalanan lalu berseru "Empat puluh hari lagi Niniwe akan ditunggang balikkan." (pasal 3:1-4). Ini merupakan nubuatan yang paling singkat dan mengambarkan usaha Yunus yang sangat minim. ${ }^{61}$ Usaha Yunus yang minim ini karena Yunus belum tulus mentaati TUHAN. Yunus lebih memilih kota Niniwe ditunggang balikkan oleh Tuhan. Kemudian Yunus keluar dari kota tersebut lalu mengamati dan menantikan apa yang terjadi terhadap Niniwe (pasal 4:5).

Nubuatan Yunus yang singkat tersebut menjadi nubuatan yang paling menobatkan orang sepanjang masa. Orang-orang yang mendengarkan seruan Yunus

\footnotetext{
60 Walton, The IPV Bible, 779

61 Jenson, Obadiah, Jonah, 73.
} 
tersebut memberikan respons yang baik. Orang-orang yang mendengar pertama langsung mengenakan kain kabung, sehingga setiap orang yang melihat bertanya tujuan dari kabung tersebut. Berita ini tersiar di kota Niniwe dan semakin banyak orang Niniwe yang berkabung. Berita ini akhirnya sampai kepada raja Niniwe. Raja Niniwe membuat ketetapan supaya setiap orang berpuasa dan mengenakan kain kabung termasuk hewan dan ternak orang Niniwe (pasal 3:5-8).

Raja Niniwe dan penduduk Niniwe melakukan puasa dan bertobat dari kejahatannya. ${ }^{62}$ Kalimat "siapa tahu" menunjukkan ungkapan skeptis menghadapi situasi yang kelihatannya tidak mungkin berubah. Raja Niniwe masih melihat lebih besar kemungkinan kota tersebut ditunggang balikkan. Nubuatan Yunus tersebut tidak ada bersifat janji pertobatan. Raja dan penduduk Niniwe belum memiliki jaminan bahwa Allah pasti akan berbalik dari murka-Nya. Raja dan penduduk Niniwe tidak mendapat janji pemulihan jika mereka bertobat. Sekalipun demikian raja dan penduduk Niniwe melakukan pertobatan dengan sungguh-sungguh. ${ }^{63}$

Kata "mungkin" menunjukkan bahwa sekalipun raja dan penduduk Niniwe masih ragu-ragu, tetapi masih ada pengharapan. Kalimat "mungkin Allah berbalik dan menyesal" menunjukkan bahwa raja dan penduduk Niniwe berharap Allah akan mengubah keputusan-Nya melihat pertobatan raja dan penduduk Niniwe. ${ }^{64}$ Respon menunjukkan sikap hati yang sungguh-sungguh bertobat. Ketika Allah melihat pertobatan raja dan penduduk Niniwe, Allah menyesal dan tidak jadi melakukan malapetaka yang telah dirancang sebelumnya.

Pertobatan Niniwe sangat mengesalkan hati Yunus. Yunus marah kepada Allah dan meminta mati saja. Kemudian untuk menghibur hati Yunus. Atas penentuan Tuhan tumbulah sebatang pohon jarak. Keesokan harinya pohon itu mati. Yunus kembali marah dan meminta mati lagi dan Yunus merasa layak marah sampai mati. Lalu TUHAN membuat perbandingan; jika Yunus sangat sayang kepada pohon yang tidak ada sedikitpun usaha apapun dilakukan Yunus terhadap tumbuhnya pohon tersebut, terlebih-lebih Tuhan sayang kepada Niniwe yang penduduknya seratus dua puluh ribu orang lebih dan banyak ternaknya (Pasal 4:6-10).

Keselamatan yang dialami oleh orang Niniwe adalah keselamatan yang holistik. Orang Niniwe selamat dari malapetaka yang direncanakan oleh Allah artinya keselalamatan fisik. Keselamatan fisik dalam konteks ini orang Niniwe tidak

\footnotetext{
62 Ibid., 76.

63 Ibid., 79.

64 Ibid.
} 
mengalami murka TUHAN. Bila kota tersebut ditunggangbalikkan oleh TUHAN, maka kemungkinan raja dan penduduk Niniwe akan meninggal.

Orang Niniwe juga mengalami keselamatan secara materi. Harta dan benda orang Niniwe juga selamat dari kerugian besar. Jika kota Niniwe jadi ditunggangbalikkan oleh Allah, maka mereka juga akan mengalami kerugian secara materi. Harta dan benda yang mereka miliki akan hancur dan seandainya penduduk Niniwe selamat secara fisik, peduduk Niniwe akan mengalami kerugian besar. Pertobatan raja dan penduduk mendatangkan keselamatan secara materi karena TUHAN tidak jadi menunggang balikkan kota tersebut. Ternak orang Niniwe juga selamat dari malapetaka tersebut.

Orang Niniwe juga mengalami keselamatan secara sosial. Pertobatan peduduk Niniwe pasti menghasilkan hubungan sosial yang baik. Nubuatan yang disampaikan oleh Yunus bisa tersiar di kota Niniwe dan sampai kepada raja menunjukkan ada awal pemulihan hubungan sosial di antara orang Niniwe. Setelah malapetaka tersebut berlalu, penduduk Niniwe juga pasti mengalami transformasi secara sosial karena mereka sudah menjadi orang yang takut akan TUHAN.

Orang Niniwe juga mengalami keselamatan secara moral. Penduduk Niniwe sebelumnya dikenal dengan kejahatannya dan kebengisannya memperlakukan bangsa lain. Setelah penduduk Niniwe mendengar nubuatan dari Yunus, penduduk Niniwe mau merendahkan hati, berbalik dari jalan-jalannya yang jahat, dan menjadi penduduk yang takut akan TUHAN.

Penduduk Niniwe juga mengalami keselamatan yang spiritual. Kejahatan Niniwe sangat besar dan sudah sampai ke hadirat TUHAN. TUHAN benci terhadap kejahatan penduduk Niniwe, tetapi TUHAN mengasihi penduduk Niniwe. Pertobatan penduduk Niniwe membuat TUHAN berbalik dari murkanya dan berkenan kepada penduduk Niniwe. Karena TUHAN berkenan kepada penduduk Niniwe maka hubungan penduduk Niniwe dengan TUHAN juga dipulihkan.

Generasi yang megalami keselamatan dari murka TUHAN pasti hidup dengan takut akan TUHAN selama hidupnya. Generasi yang megalami keselamatan ini berbeda dengan generasi berikutnya. Generasi berikutnya kemungkinan tidak lagi takut akan TUHAN karena pada akhirnya kota Niniwe hancur dan tinggal puing-puing serta tidak pernah dibangun kembali. Kehancuran ini sekaligus penggenapan Nabi Zefanya (2:13-15) dan Nabi Nahum (3:1-7).

Genarasi yang mengalami pertobatan pada saat pemberitaan nabi Yunus mengalami Intial salvation. Sekalipun dalam kitab Yunus tidak ditulis bagaimana 
generasi ini hidup setelah pertobatannya, Generasi ini pasti mengalami progressive salvation dan sampai pada the ultimate salvation.

\section{Kesimpulan}

Keselamatan dalam kitab Yunus adalah keselamatan yang holistik dan memiliki keunikan. Keselamatan secara fisik yang dialami oleh awak kapal dan para penumpang memimpin mereka mengalami keselamatan spiritual. Keselamatan yang dialami oleh Yunus adalah keselamatan dari kematian fisik, tetapi kitab Yunus tidak menjelaskan pertobatan nabi Yunus. Pertobatan nabi Yunus masih menjadi misteri. Keselamatan yang dialami oleh orang Niniwe keselamatan yang holistik karena meliputi keselamatan secara fisik, materi, moral dan juga spiritual.

Konsep keselamatan dalam kitab Yunus tidak berbicara keselamatan bisa hilang atau tidak hilang. Kitab Yunus tidak fokus membahas jaminan dan kepastian keselamatan setiap orang percaya. Kitab Yunus mengambarkan secara utuh keselamatan yang holistik ketika seseorang bertobat. Dalam kitab Yunus pertobatan adalah langkah awal untuk mengalami keselamatan secara holistik.

Kitab Yunus menggambarkan bahwa keselamatan adalah kedaulatan TUHAN. Tuhan bisa saja menghalangi Yunus sebelum berlayar ke tarsis, tetapi karena TUHAN punya rencana keselamatan kepada para awak kapal tersebut. TUHAN izinkan Yunus pergi ke Tarsis supaya Yunus memperkenalkan TUHAN kepada para awak kapal.

Pengalaman Yunus dalam perut ikan juga menggambarkan kedaulatan TUHAN sepenuhnya atas hidup Yunus. TUHAN juga berdaulat atas keselamatan hidup Yunus. Yunus menyadari bahwa Yunus tidak bisa menyelamatkan dirinya sendiri, maka TUHAN yang turun tangan menyelamatkan Yunus lewat ikan besar tersebut. Sekalipun Yunus memiliki pengalaman yang luar biasa selama tiga hari dalam perut ikan, tidak menunjukkan bahwa Yunus bertobat. Sekalipun demikian, Yunus tetap harus pergi ke Niniwe.

Kitab Yunus juga menggambarkan bahwa TUHAN juga mengasihi bangsabangsa asing. TUHAN membenci dosa semua orang, tetapi kasih TUHAN terbuka buat bangsa-bangsa bukan hanya bangsa Israel. TUHAN berdaulat sepenuhnya atas keselamatan bangsa-bangsa.

Konsep keselamatan dalam kitab Yunus tidak hanya menggambarkan keselamatan terhindar dari murka TUHAN dalam kekekalan, tetapi keselamatan harus meliputi segala aspek kehidupan manusia. Seharusnya ketika membahas keselamatan tidak hanya berbicara jaminan dan kepastian keselamatan, tetapi mendalami bagiamana keselamatan itu mempengaruhi segala aspek kehidupan 
setiap orang percaya sehingga setiap orang percaya mengalami keselamatan yang holistik atau seutuhnya. Keselamatan tidak hanya menonjolkan aspek-aspek spiritual saja, tetapi harus memperhatikan aspek, fisik, materi, sosial dan moral.

Tahapan keselamatan yang paling jelas digambarkan dalam kitab Yunus adalah initial salvation secara khusus bagi para awak kapal dan penduduk Niniwe. Progressive salvation digambarkan dari pengalaman dan pergumulan Yunus terhadap penggilannya terhadap Niniwe. Dalam kitab Yunus tidak ada menyinggung the ultimate salvation secara literal karena kitab Yunus lebih mengambarkan keselamatan terbuka untuk bangsa-bangsa asing yang mau bertobat seperti kota Niniwe. Jadi secara teologis kitab Yunus lebih menekankan kepada Initial salvation.

\section{Referensi}

Allison, Gregg, Historical Theology: An Introduction to Christian Doctrine. Grand Rapids: Zondervan, 2011.

Aquinas, Thomas, Summa Theologica (ErthNow, 2013). Kindle.

Beale, G.K. dan Carson, D.A. (eds), Commentary of the New Testament Use of the Old Testament. Grand Rapids: Baker Academic, 2007. EPUB

Grudem, WayneSystematic Theology: An Introduction to Biblical Doctrine. Grand Rapids; Zondervan, 1994.

Henry, Matthew. Matthew Hendry's Commentary in one Volume. Grand Rapids: Zondervan, 1961.

Jenson, Philip Peter, Obadiah, Johan, Micah: A Theological Commentary. New York: T\&T Carlk, 2008.

Limburg James, Jonah: A Commentary. Kentucky: John Knox Press, 1993.

Marbun, Tolop Oloan, Progressive Salvation: Studi Pustaka Progressive Salvation dari Sudut Pandang Moderate Calvinist berdasarkan pemikiran Norman Geisler. Dr. Diss., STT Cipanas, Cipanas, 2020.

Martens Elmers A., God's Design: A focus On Old Testament Theology. Bakers Books, Grand Rapids, 1994.

Osborne, Grant R., The Hermeneutical Spiral: A Comprehensive Introduction to Biblical Interpretation. Illinois: InterVarsity, 1991.

Pasombo, Resti Arrena, Kajian Biblika tentang Kisah Yunus sebagai Tipologi Kematian dan Kebangkitan Kristus .Skrp, Toraja: STAKEN, 2019.

Preuss, Horst Diestrich, Old Testamen Theology Vol.2, Kentucky: Westminster John Knock Press, 1992.

Sabdono, Erastus Apakah Keselamatan Bisa Hilang? .Jakarata: Rehobot Literatur, 2019. 
Solomom, Robert M., Allah sang pemburu: Pelajaran-pelajaran dari kitab Yunus, terj. Arvin Saputera.TK.: PT Duta Harpan Dunia, 2017.

Schaff, Pillip, Nicene and Post Nicene Father Series 1. Grand Rapids: Christian Classics Ethereal Library.

Tillich, Paul, Systematic Theology, Vol. 2. Chicago: The University of Chicago Press, 1962.

Walton, John H. at.all., The IVP Bible Background Commentary: Old Testament. Illinois: IPV Academic, 2000.

Wiersbe,Waren W., The Wiersbe Bible Commentary. Colorado Springs: David C Cook, 2007.

Wilkin, Robert N. Ed. The Grace New Testatament Commentary.Denton: Grace Evangelical Sociey, epub.

Yoder Perry B., Shalom: The Bible's Word for Salvation, Justice and Peace. Indiana: Evangel Publishing House, 1987.

\section{JURNAL}

Djuharto, Gumulya, "ANALISA PANGGILAN YUNUS DALAM KITAB YUNUS 1:1-17", Jurnal Theologia Aletheia, Vol. 16 No. 6 (Maret 2014).

Maiaweng Peniel, "UTUSLAH AKU”: EKSPOSISI YUNUS PASAL 3-4 TENTANGA PENGUTUSAN NABI YUNUS BERDASARKAN PERSFEKTIF ALLAH MENYESAL", Jurnal Jaffray, Vol. 10. No. 2 (Oktober 2012).

Marbun T.O., SHALOM SEBAGAI KONSEP KESELAMATAN YANG HOLISTIK DALAM PERJANJIAN LAMA," JURNAL LUXNOS, 5 (2) (2019), 147-157. Retrieved from http://luxnos.sttpd.ac.id/index.php/20_luxnos_20/article/view/23

Queency Wauran, at.all., (2015). Prosiding Kitab Yunus: Pengajaran Tentang Penentuan TUHAN Dalam Kitab Yunus. 10.13140/RG.2.1.3675.7847.

\section{WEBSITE}

www.jewfaq.com/m/search.shtml?Keyowords=sheol (diakses 22 Maret 2020). 